\title{
Impact of the wasting disease pathogen, Labyrinthula zosterae, on the photobiology of eelgrass Zostera marina
}

\author{
Peter J. Ralph ${ }^{1, *}$, Frederick T. Short ${ }^{2}$ \\ ${ }^{1}$ Institute for Water and Environmental Resource Management, University of Technology, Sydney, PO Box 123, \\ Broadway New South Wales 2007 Australia \\ ${ }^{2}$ Jackson Estuarine Laboratory, University of New Hampshire, 85 Adams Point Road, Durham, New Hampshire 03824, USA
}

\begin{abstract}
Labyrinthula zosterae is clearly shown to be a primary pathogen of eelgrass Zostera marina L., not merely a secondary infection of senescent leaves or an indication of decomposition. The results of this investigation using a Diving-PAM fluorometer indicate that the regions of tissue photosynthetically compromised by Labyrinthula are substantially larger than previously thought. Labyrinthula moves through Zostera marina tissue at a rate of up to $0.8 \mathrm{~mm} \mathrm{~h}^{-1}$ during daylight periods. The photosynthetic efficiency of apparently healthy green leaf tissue can be reduced by almost $50 \%$ in areas up to $3 \mathrm{~mm}$ from a necrotic region infected with Labyrinthula. Once a necrotic spot expands to bisect the eelgrass leaf, the condition of all acropetal tissue is diminished; leaf tissue up to $5 \mathrm{~cm}$ away has severely reduced photosynthetic activity.
\end{abstract}

KEY WORDS: Eelgrass $\cdot$ Zostera marina $\cdot$ Slime mold $\cdot$ Labyrinthula $\cdot$ Seagrass $\cdot$ Protist $\cdot$ Wasting disease

\section{INTRODUCTION}

During the 1930's, 'wasting disease' decimated the eelgrass Zostera marina L. meadows along the Atlantic Coast of North America and Europe with over 90\% loss (Muehlstein 1989). Speculations concerning the causative agents of the wasting disease have been numerous, including pathogenic microorganisms, salinity, temperature, irradiance, drought and oil pollution (Short et al. 1988, Muehlstein 1989). It has now been shown that the eelgrass wasting disease is caused by infection with a marine slime mould-like protist, Labyrinthula zosterae Porter \& Muehlstein (phylum Labyrinthulomycota) (Short et al. 1987, Muehlstein et al. 1991). Wasting disease continues to affect Z. marina meadows in North America and Europe with variable degrees of loss, though none to date as catastrophic as the epidemic of the 1930s (Short et al. 1986, 1988, 1993).

*E-mail: peter.ralph@uts.edu.au
Wasting disease infection is spread either through direct contact with an infected growing plant or drifting detached plant parts. The initial symptoms are black-brown dots or streaks on the leaves, which, as the infection develops, coalesce to form patches, larger blackened spots, and longer streaks; ultimately, the plant dies (Short et al. 1988, Muehlstein 1989). Microscopic examination of necrotic tissues has revealed that the pathogen moves rapidly (175 $\mu \mathrm{m} \mathrm{min}^{-1}$ ) through tissues, penetrating cell walls. The protist appears to initiate enzymatic degradation of the cell wall, followed by destruction of the cytoplasmic contents of the seagrass leaf cell (Muehlstein 1992). The exact mechanism of mortality resulting from Labyrinthula zosterae infection is still not known.

Both Renn (1936) and Young (1938) observed Labyrinthula cells within eelgrass leaf tissue outside of the actual blackened region. Renn (1936) also described the effect of infection on leaf cellular components, including disorganisation of chloroplasts and disintegration of cell nuclei, which resulted in 'dark resinous inclusions' appearing along the cell walls. Vergeer et 
al. (1995) suggested that the characteristic spots were the result of enzymatic browning from L. zosterae.

Den Hartog $(1987,1996)$ suggested that Labyrinthula functions as a secondary decomposer of senescent leaf material. Many authors have postulated that the onset of Labyrinthula infection in Zostera marina is linked to already stressed seagrasses (Young 1937, Tutin 1938, Rasmussen 1977), as they believe healthy tissue can generally resist infection by this ubiquitous marine pathogen (Vergeer \& den Hartog 1994). Labyrinthula has been demonstrated to be the etiological agent of the wasting disease using Koch's postulates (Short et al. 1987). Further studies have demonstrated that the infectious slime mold $L$. zosterae is a host-specific pathogen transferred by direct contact of plants (Muehlstein et al. 1988, 1991). Although it has been demonstrated that salinity plays a role in regulating disease activity (Burdick et al. 1993), the actual conditions leading to broad-scale outbreaks of the disease are yet to be understood.

The recent reoccurrence of the wasting disease in the northwest Atlantic has provided an opportunity to observe fluctuations in infected eelgrass populations and to relate these changes to environmental conditions. The role of salinity in regulating the activity of Labyrinthula illustrates the importance of careful monitoring and assessment of environmental factors in conjunction with disease activity (Burdick et al. 1993). Labyrinthula activity is clearly controlled by the salinity of its surrounding media; salinities below 20 to $25 \mathrm{ppt}$ reduce disease activity and allow eelgrass to recover from the infection (Muehlstein et al. 1988, Burdick et al. 1993). Temperature and light were implicated in the 1930s epidemic, with reports of elevated temperature associated with disease outbreak (Rasmussen 1977) and increased wasting disease occurring at protracted low levels of insolation (Tutin 1938). No recent conclusive evidence further elaborates the possible impacts of temperature and light on wasting disease (Short et al. 1988), although they likely have a role through their influence on eelgrass metabolism.

Buchsbaum et al. (1990) found that eelgrass with higher phenolic levels was less susceptible to Labyrinthula infection. Vergeer et al. (1995) found that Labyrinthula infection resulted in elevated levels of phenolics in Zostera marina leaves, levels that were greater when samples were taken closer to a lesion. The role of such secondary compounds, as well as the regulation of plant metabolism, requires additional research. Infections of Labyrinthula have been shown to affect various aspects of seagrass physiology. For example, it was found that Labyrinthula reduced Thalassia testudinum production to below zero when more than $25 \%$ of the leaf blade was infected (Durako \& Kuss 1994). Also, respiration rates of infected tissue were up to 3 times higher than rates in non-infected leaves. Changes in the slope of the light limiting region of the photosynthesis-irradiance curve $(\alpha)$ were found for seagrass tissue with extensive necrosis. It was demonstrated that Labyrinthula impairs photosynthesis in T. testudinum (Durako \& Kuss 1994).

The aim of this investigation was to demonstrate the extent of photosynthetic impairment due to Labyrinthula infection beyond the blackened leaf tissue, and estimate the rate of impact of photosynthetic activity. We used the Diving-PAM and Microfibre-PAM to test levels of photosynthetic activity (Ralph et al. 1998, Beer et al. 2000) within leaves from healthy to infected eelgrass tissue, and changes in photosynthetic rates as the necrotic tissue expanded.

\section{MATERIALS AND METHODS}

Culture of diseased Zostera marina. Eelgrass plants were maintained in a series of flow-through mesocosms $\left(1 \mathrm{~m}^{3}\right)$ in a glasshouse at the Jackson Estuarine Laboratory, University of New Hampshire, USA $\left(43^{\circ} 5^{\prime} \mathrm{N}\right.$, $\left.70^{\circ} 50^{\prime} \mathrm{W}\right)$. The eelgrass was transplanted from beds in Great Bay, New Hampshire, 8 mo before the photosynthesis experiments. Disease symptoms developed on eelgrass in 5 of the 8 mesocosms as a result of the presence of the pathogen in the field-collected plants. Disease spread to all shoots in the infected mesocosms. At the time of the experiments in July 1999, water temperature was $22 \pm 1^{\circ} \mathrm{C}$ and salinity was 32 to 34 ppt. Young diseased leaves were randomly selected in the infected mesocosms, and chl a fluorescence measurements (Schreiber et al. 1994) were performed in situ using a Diving-PAM (Walz GmbH, Effeltrich, Germany) to determine effective quantum yield $\left(\Delta F / F_{\mathrm{m}}{ }^{\prime}\right)$ and maximum quantum yield $\left(F_{\mathrm{v}} / F_{\mathrm{m}}\right)$. Measurements were performed on either leaf nos. 2 or 3 of the plant, so that epiphyte interference was minimal.

Disease profile along an infected leaf blade. Labyrinthula infection was detected by visual assessment of young growing leaf blades of Zostera marina. Blackened tissue was identified on sample leaves. Chl a fluorescence measurements were taken with the DivingPAM with a $1 \mathrm{~mm}$ acrylic fibre-optic probe from the edge of the black tissue, moving in $1 \mathrm{~mm}$ increments into the green tissue in both directions, towards the leaf tip (acropetal) and towards the meristem (basipetal).

Effect of disease band across entire leaf blade. Sample leaves were selected where Labyrinthula infection had advanced to the point that the necrotic (blackened) area extended across the entire width of the eelgrass blade, while leaving zones of green tissue above and below the blackened band (Fig. 1). Fluorescence measurements were made in situ with the Diving- 


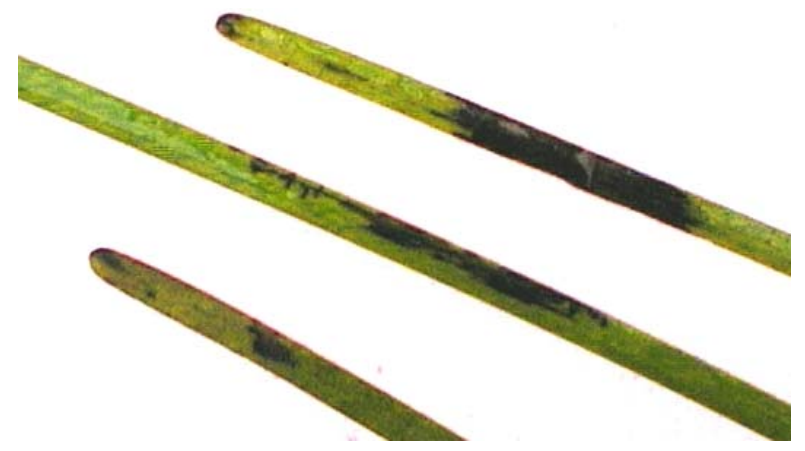

Fig. 1. Photograph of infected eelgrass tissues, showing complete blackened region across entire blade, black spots and black streaks

PAM, basipetal and acropetal to the infected black band. The measurements were made about $5 \mathrm{~cm}$ from the black tissue. Control measurements were performed on healthy leaves (no blackened band or apparent infection) to illustrate that the response was not associated with age of tissue (i.e. senescence). Control measurements of maximum quantum yield $\left(F_{\mathrm{v}} / F_{\mathrm{m}}\right)$ were made at least $10 \mathrm{~cm}$ above the sheath and separated by approximately 10 to $15 \mathrm{~cm}$.

Migration of Labyrinthula and effect on tissue photosynthesis. Sample leaves having new active Labyrinthula infection (with a single black spot 1 to $3 \mathrm{~mm}$ in diameter) were selected and monitored over a period of $24 \mathrm{~h}$ to track the progress of the infection, using the Microfibre-PAM (Walz GmbH) with a $100 \mu \mathrm{m}$ fibre-optic. The $100 \mu \mathrm{m}$ fibre-optic was gently placed on the surface of the leaf tissue beyond the apparent disease front, using a micromanipulator MM33 (Märzhäuser, Wetzlar, Germany). Leaves were maintained in a submerged trough within a mesocosm, to prevent movement while being measured, but allowing full irradiance and water flow. Every $2 \mathrm{~h}$ the length of the blackened spot was measured and the effective quantum yield of the tissue at the location of the probe was also recorded. Control leaves were measured that did not have Labyrinthula symptoms $(\mathrm{n}=6)$.

Chlorophyll fluorescence measurements. Effective quantum yield $\left(\Delta F / F_{\mathrm{m}}{ }^{\prime}=\left(F_{\mathrm{m}}{ }^{\prime}-F\right) / F_{\mathrm{m}}{ }^{\prime}\right)$ is a measure of Photosystem II photosynthetic activity, which is measured under ambient light conditions, whereas maximum quantum yield $\left(F_{\mathrm{v}} / F_{\mathrm{m}}=\left(F_{\mathrm{m}}-F_{\mathrm{o}}\right) / F_{\mathrm{m}}\right)$ is measured after 5 min dark-adaptation. Both of these variables have no units, as they are ratios of fluorescence measurements. The ratio $F_{\mathrm{v}} / F_{\mathrm{m}}$ indicates the proportion of Photosystem II reaction centres that are capable of converting captured light into photosynthetic energy. This ratio is a convenient measure of the maximum potential quantum yield of Photosystem II, and is therefore inversely proportional to photochemical stress.
Minimum fluorescence $\left(F_{\mathrm{o}}\right)$ occurs when all Photosystem II reaction centres are open. Subsequently, a saturating pulse of light closes the traps, the maximum fluorescence yield $\left(F_{\mathrm{m}}\right)$ is measured. $F_{\mathrm{o}}$ and $F_{\mathrm{m}}$ are measured after a period of darkness when the photochemical process has completely relaxed. $F_{\mathrm{m}}{ }^{\prime}$ and $F$ (used for effective quantum yield) are the equivalent of $F_{\mathrm{m}}$ and $F_{\mathrm{o}}$ but are measured under ambient light conditions. Effective quantum yield also measures Photosystem II photosynthetic activity; however, it is strongly influenced by irradiance, down-regulation and nonphotochemical quenching (Schreiber et al. 1994).

Rapid light curves (RLC) describe the relationship between electron transport rate (ETR) and irradiance. ETR is determined according to the following equation (Schreiber et al. 1994):

$$
\mathrm{ETR}=\Delta F / F_{\mathrm{m}}{ }^{\prime} \times 0.84 \times 0.5 \times \mathrm{PAR}
$$

where $\Delta F / F_{\mathrm{m}}$ ' is the effective quantum yield, 0.84 is the absorption coefficient, 0.5 compensates for irradiance being split between 2 photosystems, and PAR is the photosynthetically active radiation. Rapid light curve measurements were performed using 8 incremental $10 \mathrm{~s}$ steps of irradiance from 0 to $1520 \mu \mathrm{mol}$ photon $\mathrm{m}^{-2} \mathrm{~s}^{-1}$ (Ralph et al. 1998). A series of RLCs were measured on infected (necrotic) regions of eelgrass leaves $(n=6)$, intermediate regions (5 $\mathrm{cm}$ from necrotic tissue), and healthy tissue (10 $\mathrm{cm}$ from necrotic).

Statistics. One-way ANOVA was used to assess differences between zones around the necrotic areas (Fig. 2). Tukey's HSD test was subsequently performed to identify which treatments in the ANOVA model were similar. A 2-sample $t$-test was performed to assess differences between the impact of Labyrinthula on either side of the necrotic area (Table 1).

\section{RESULTS}

\section{Disease profile along an infected leaf blade}

A zone of green tissue up to $4 \mathrm{~mm}$ from a blackened (diseased) region had significantly reduced

Table 1. Effect of disease across the entire leaf width on the maximum quantum yield $\left(F_{\mathrm{v}} / F_{\mathrm{m}}\right)$ above and below the band of diseased tissue. Mean $F_{\mathrm{v}} / F_{\mathrm{m}}$ ratio $\pm \mathrm{SE}(\mathrm{n}=6)$. Results of 2 -sample $t$-test, samples grouped by position. $\mathrm{p}<0.05$ is significant

\begin{tabular}{|lcc|}
\hline Position & Diseased tissue & Control tissue \\
\hline Basipetal (towards base) & $0.509 \pm 0.050$ & $0.484 \pm 0.065$ \\
Acropetal (towards tip) & $0.337 \pm 0.091$ & $0.490 \pm 0.082$ \\
$\mathrm{p}$ & 0.004 & 0.885 \\
\hline
\end{tabular}




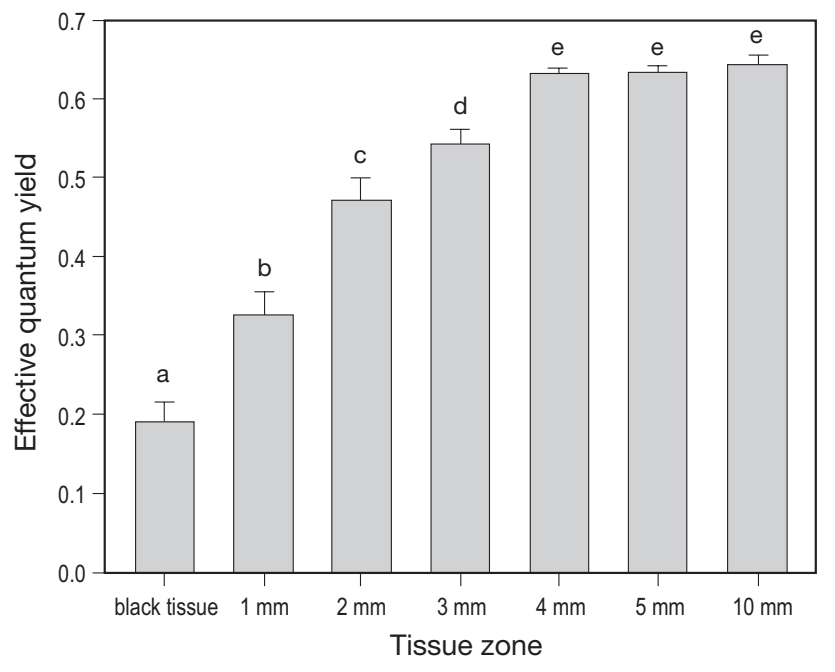

Fig. 2. Disease profile along an infected eelgrass leaf blade. Mean value of effective quantum yield $\pm \mathrm{SE}(\mathrm{n}=6)$. Measurements were taken in both directions (basipetal and acropetal from the infected (blackened) zone. Letters identify treatments that are significantly different according to Tukey's HSD test. Units of effective quantum yield are arbitrary

photosynthetic activity compared to tissue unaffected by Labyrinthula (Fig. 1), demonstrating that the infection is located in tissues beyond the immediate region of blackened tissue. The green tissue immediately adjacent to the blackened zone $(1 \mathrm{~mm})$ had an effective quantum yield of $\sim 50 \%$ that of healthy tissue (10 mm away). The further away from the blackened tissue $(2,3$ and $4 \mathrm{~mm})$, the greater the effective quantum yield (i.e. the healthier). There was no significant difference in effective quantum yield of the samples taken 4,5 and $10 \mathrm{~mm}$ from the disease front.

\section{Effect of disease across entire leaf blade}

Patches of diseased tissue that extend across the entire width of a leaf appear to influence the maximum quantum yield $\left(F_{\mathrm{v}} / F_{\mathrm{m}}\right)$ of tissue sampled above (acropetal to) such patches. Although tissue at the distal end of the blades is older and therefore might be expected to produce lower quantum yields due to age, the control data show that the response is due to infected tissue across the width of the leaf (Table 1). Acropetal regions showed significantly lower maximum quantum yield than did either the corresponding basipetal region or the control tissue. There was no significant difference between the response of the basipetal side and the control $(\mathrm{p}=$ $0.483)$.

\section{Migration of Labyrinthula and effect on tissue photosynthesis}

Tracking the expansion of a single black spot showed the movement of the disease front through the leaf and documented the photosynthetic response as the disease approached and overtook the location of the probe. The zone of diseased tissue increased at a constant rate of just under $1 \mathrm{~mm} \mathrm{~h}^{-1}$ during daylight hours from time $0(08: 00 \mathrm{~h})$ until late afternoon $(16: 00 \mathrm{~h})$ (Fig. 3). During the night, the region of blackened tissue did not expand substantially $\left(<0.012 \mathrm{~mm} \mathrm{~h}^{-1}\right)$. The measurement of quantum yield $\left(\Delta F / F_{\mathrm{m}}{ }^{\prime}\right)$ beyond the margin of the single black spot was initially equivalent to the control leaf but showed a substantial decrease in photosynthetic activity (Schreiber et al. 1994) as the spot expanded over the $24 \mathrm{~h}$ period, dropping from 0.65 (healthy response) to approximately 0.2 . As the disease front migrated further through green tissue, a decline in effective quantum yield occurred.

\section{Paired rapid light curves}

Rapid light curves of healthy Zostera marina tissue showed a normal response to increasing irradiance (see Ralph et al. 1998). Healthy tissue showed increasing ETR up to 400-800 $\mu$ molphoton $\mathrm{m}^{-2} \mathrm{~s}^{-1}$, with down-regulation occurring only at the highest irradiance levels (Fig. 4). In comparison, the blackened tissue showed limited photosynthetic activity and only at low irradiance levels (Fig. 4). Intermediate tissue (at the edge of the diseased areas) showed increasing photosynthetic activity only at irradiances $<200 \mu \mathrm{mol}$ photon $\mathrm{m}^{-2} \mathrm{~s}^{-1}$, while at higher irradiances the ETR

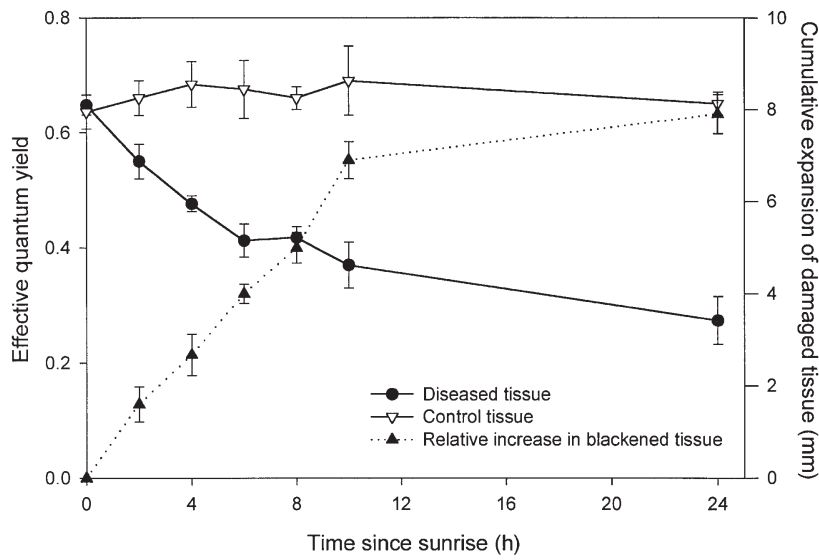

Fig. 3. Rate of increase in blackened tissue in comparison to effective quantum yield $\left(\Delta F / F_{\mathrm{m}}{ }^{\prime}\right)$. Mean value of effective quantum yield (diseased and control tissue) and distance of expanding blackened region \pm SE $(n=6)$. Units of maximum quantum yield are arbitrary 


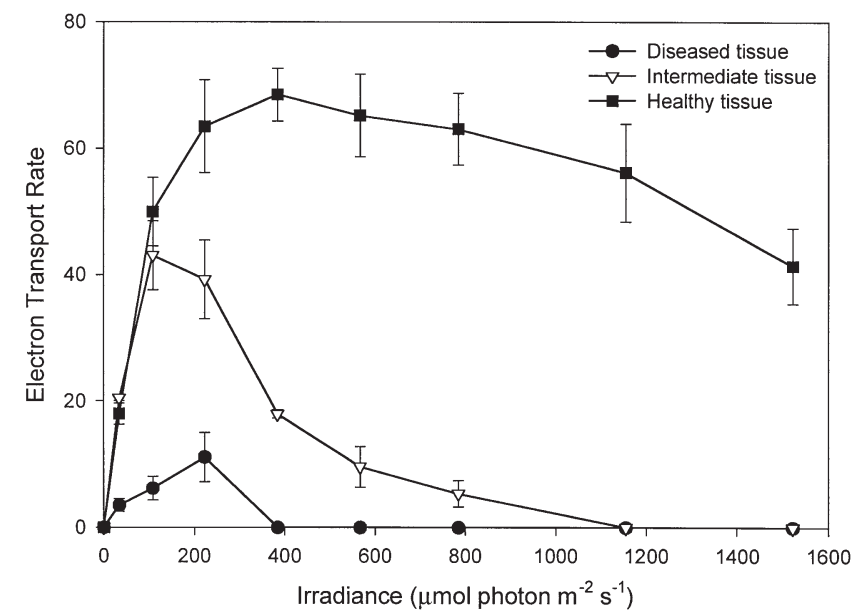

Fig. 4. Rapid light curves of 3 stages of Labyrinthula infection: damaged (blackened), intermediate (adjacent to blackened) and healthy tissue samples. Data are the mean \pm SE $(n=6)$. Units of ETR are $\mu \mathrm{mol}$ electron $\mathrm{m}^{-2} \mathrm{~s}^{-1}$ and irradiance are $\mu \mathrm{mol}$ photon $\mathrm{m}^{-2} \mathrm{~s}^{-1}$

declined significantly (Fig. 4). This response was lower than for healthy tissue, but greater than for blackened tissue. There was substantially reduced ETR at irradiances greater than $200 \mu$ mol photon $\mathrm{m}^{-2} \mathrm{~s}^{-1}$ in blackened tissue, and intermediate tissue also showed a similar photoinhibitory or photodamage response (i.e. loss of photosynthesis at high irradiances). Photosynthesis did not recover overnight, indicating that this response was due to chronic photoinhibition or photodamage, not merely diurnal down-regulation. Healthy tissue did not show down-regulation until at least $1200 \mu$ molphoton $\mathrm{m}^{-2} \mathrm{~s}^{-1}$. Rapid light curves are effective for demonstrating the impact of Labyrinthula on photosynthesis in eelgrass leaves. The slope of the light-limiting region of the RLC $(\alpha)$ was also considerably reduced in infected tissue (Fig. 4).

\section{DISCUSSION}

Muehlstein et al. (1991) isolated Labyrinthula in green eelgrass tissue up to $5 \mathrm{~mm}$ from a lesion. The expansion of areas infected by the wasting disease and the concomitant movement of Labyrinthula through eelgrass tissue caused a measurable impact on eelgrass photosynthesis in our study. We show that much greater amounts of eelgrass tissue are compromised by the damage caused by Labyrinthula than simply the visibly blackened tissue, as previously thought.

Impairment of photosynthesis in the infected Zostera marina blades was apparent when examining the rate of photosynthetic activity at the light-limited region of the RLC (Fig. 4). Renn (1936) observed that as the dis- ease progressed, chloroplasts initially clumped in the centre or perimeter of the cells, changed colour, and then as the chloroplasts disintegrated their fragments dispersed throughout the cell. A similar response was demonstrated by Durako \& Kuss (1994) using traditional P-I curves with Thalassia testudinum.

Once the disease has made substantial progress and created a disease band across the blade, the photosynthetic activity of tissue above (acropetal to) the damaged band is strongly inhibited, through the tissue remains green. Solute transport through the vascular system appears to be affected by the development of Labyrinthula infection, which could be associated with a reduction or loss of vascular transport through the diseased band (Renn 1936, Durako \& Kuss 1994). The unidirectional response of the leaf to infection implies that some form of transport is impacted, as the photosynthetic activity remains the same as in the uninfected control tissue below the diseased band. It is unclear whether the diseased band blocks the flow of nutrients to the acropetal portion of the leaf, whether transport of photosynthetic products to the meristem is restricted, or if oxygen transport is inhibited. Durako \& Kuss (1994) suggested that loss of oxygen transport in the plants may cause root hypoxia as well as additional stress conditions, leading to die-off. The implication of such reduction to overall plant photosynthesis would be reduced eelgrass health and productivity beyond the local areas of infected tissue. Such infection across the width of a leaf could cause substantial photosynthetic stress to the eelgrass, and limit its ability to withstand the impact of additional synergistic stress conditions, such as root anoxia, salinity fluctuations, turbidity or temperature changes.

Regions of mature leaves with advanced disease damage will have reduced photosynthetic activity in the region acropetal to a large black spot. Extrapolated to the population level, the impact of Labyrinthula would therefore affect much more tissue than previously considered. The results of the present study suggest that a wasting index (visual assessment of necrotic tissue, Burdick et al. 1993) implies a far greater impact on the plant's photosynthetic activity. For example, in eelgrass leaves with $50 \%$ wasting index, no net photosynthetic production is likely and plants with leaves having even higher (>50\%) wasting index often drop their most infected leaves (F.T.S. pers. obs.). Durako \& Kuss (1994) found that once the Labyrinthula lesions affected $>25 \%$ of Thalassia leaf tissue, the net photosynthetic rate was zero. Once infection has reached $25 \%$, it is also likely that infected bands will bisect the leaf blade, further reducing the overall photosynthesis of the leaf, especially in the acropetal region (Fig. 2).

Vergeer \& Develi (1997) suggested that this disease is 'mostly restricted to the senescent tissue of old leaves' 
and is therefore the beginning of a decomposition process. While the highest levels of Labyrinthula exist in the blackened and decaying parts of eelgrass plants, Muehlstein et al. (1991) also found Labyrinthula present, albeit less frequently than in black tissue, in the green tissue within $5 \mathrm{~mm}$ of a lesion. We have shown that these green areas of 'healthy-looking' tissue have severely reduced photosynthetic activity.

Earlier, Rasmussen (1977) stated that Labyrinthula could be found in what he called 'healthy, normal Zostera without any signs of disease' (ahead of the infection zone: Renn 1936, Young 1938). Rasmussen (1977) concluded that Labyrinthula 'is not of primary, but secondary, importance as a disease carrier'; finding the pathogen in green tissue without obvious disease symptoms, he had no means of identifying that the green tissue was impacted by the pathogen. His assumption was that if tissue was green, it was healthy. The present investigation illustrates that Labyrinthula damages green leaf tissue, not only blackened areas or senescent leaves. Our study clearly confirms the previous demonstration of Koch's postulates (Short et al. 1987) that Labyrinthula is a primary pathogen, by showing that the apparently healthy tissue around the infection is also compromised, with a decline of photosynthesis proportional to the proximity of the blackened region (Fig. 2). Labyrinthula zosterae is more than a secondary infection agent or a secondary decomposer of damaged eelgrass tissue, but rather is a primary pathogen.

The rate of spread of Labyrinthula within eelgrass leaves reached $0.8 \mathrm{~mm} \mathrm{~h}^{-1}$ during daylight periods and was much slower during the night. As the disease progresses into green tissue, the photosynthetic activity of the tissue in that region declines dramatically. Durako \& Kuss (1994) postulated that Labyrinthula infection reduced the pigment level; we have demonstrated that photosynthetic efficiency is substantially reduced when the disease progresses. Muehlstein et al. (1991) demonstrated that the motility of Labyrinthula spindle cells on culture plates was $175 \mathrm{~mm} \mathrm{~min}{ }^{-1}$, which is $\sim 10 \mathrm{~mm} \mathrm{~h}^{-1}$, indicating that the rate of progress of the disease front we measured within Zostera marina leaves is achievable by this pathogen. Beyond this, our work shows that the effective quantum yield of eelgrass photosynthesis decreases directly with disease advancement. Additionally, as the disease progresses and the blackened tissue expands, the photosynthetic response to light of the still green (intermediate) tissue diminishes at higher light levels. Thus, the spread of the pathogen not only affects the blackened tissue but alters the photosynthetic capability of the surrounding green leaf.

The ecological significance of this study requires a rethinking of the disease infection condition of eel- grass populations. Even apparently healthy eelgrass beds, with minor disease symptoms, could be exposed to substantial photosynthetic stress by low levels of Labyrinthula infection. The impact of Labyrinthula infection is particularly important with the confirmation that the pathogen is a primary infectious agent of otherwise healthy green eelgrass tissue.

Acknowledgements. We thank graduate and undergraduate students at UNH for mesocosm work, and Cathy Short for editing. The project was funded by the Jackson Estuarine Laboratory at the University of New Hampshire, a Hatch grant from USDA and an Institutional grant from University of Technology, Sydney. This is Jackson Estuarine Laboratory contribution no. 360 .

\section{LITERATURE CITED}

Beer S, Bjork M, Gademann R, Ralph PJ (2000) Measurements of photosynthesis in seagrasses. In: Short FT, Coles R (eds) Global seagrass research methods. Elsevier Publishers, The Netherlands, p 183-198

Buchsbaum RN, Short FT, Cheney DP (1990) Phenolic-nitrogen interactions in eelgrass, Zostera marina L.: possible implications for disease resistance. Aquat Bot 37:291-297

Burdick DM, Short FT, Wolf J (1993) An index to assess and monitor the progression of the wasting disease in eelgrass, Zostera marina. Mar Ecol Prog Ser 94:83-90

den Hartog C (1987) Wasting disease and other dynamic phenomena in Zostera beds. Aquat Bot 27:3-14

den Hartog C (1996) Sudden decline of seagrass beds: 'wasting disease' and other disasters. In: Kuo J, Phillips RC, Walker DI, Kirkman H (eds) Seagrass biology: proceedings of an international workshop. 25-29 Jan 1996, Rottnest Island, Western Australia. Faculty of Sciences, University of Western Australia, p 307-314

Durako MJ, Kuss KM (1994) Effects of Labyrinthula infection on the photosynthetic capacity of Thalassia testudinum. Bull Mar Sci 54:727-732

Muehlstein LK (1989) Perspectives on the wasting disease of eelgrass Zostera marina. Dis Aquat Org 7:211-221

Muehlstein LK (1992) The host-pathogen interaction in the wasting disease of eelgrass, Zostera marina. Can J Bot 70: 2081-2088

Muehlstein LK, Porter D, Short FT (1988) Labyrinthula sp., a marine slime mold producing the symptoms of wasting disease in eelgrass, Zostera marina. Mar Biol 99:465-472

Muehlstein LK, Porter D, Short FT (1991) Labyrinthula zosterae sp. nov., the causative agent of wasting disease of eelgrass, Zostera marina. Mycologia 83:180-191

Ralph PJ, Gademann R, Dennison WC (1998) In situ seagrass photosynthesis measured using a submersible pulse amplitude modulated fluorometer. Mar Biol 132: 367-373

Rasmussen E (1977) The wasting disease of eelgrass (Zostera marina) and its effects on environmental factors and fauna. In: McRoy CP, Helfferich C (eds) Seagrass ecosystems. Marcel Dekker, New York, p 1-51

Renn CE (1936) The wasting disease of Zostera marina. A phytological investigation of the diseased plant. Biol Bull 70:148-158

Schreiber U, Bilger W, Neubauer C (1994) Chlorophyll fluorescence as a nonintrusive indicator for rapid assessment 
of in vivo photosynthesis. In: Schulze ED, Caldwell MM (eds) Ecophysiology of photosynthesis. Springer, Berlin, p 49-70

Short FT, Ibelings BW, den Hartog C (1988) Comparison of a current eelgrass disease to the wasting disease of the 1930s. Aquat Bot 30:295-304

Short FT, Mathieson AC, Nelson JI (1986) Recurrence of the eelgrass wasting disease at the border of New Hampshire and Maine, USA. Mar Ecol Prog Ser 29:89-92

Short FT, Muehlstein LK, Porter D (1987) Eelgrass wasting disease: cause and recurrence of a marine epidemic. Biol Bull 173:557-562

Short FT, Burdick DM, Wolf J, Jones GE (1993) Eelgrass in estuarine research reserves along the East Coast, U.S.A., Part I: Declines from pollution and disease and Part II: Management of eelgrass meadows. NOAA Coastal Ocean Program Publ

Editorial responsibility: Otto Kinne (Editor), Oldendorf/Luhe, Germany
Tutin TG (1938) The autecology of Zostera marina in relation to the wasting disease. New Phytol 37:50-71

Vergeer LHT, den Hartog C (1994) Omnipresence of Labyrinthulaceae in seagrass. Aquat Bot 48:1-20

Vergeer LHT, Develi A (1997) Phenolic acid in healthy and infected leaves of Zostera marina and their growth-limiting properties towards Labyrinthula zosterae. Aquat Bot 58:65-72

Vergeer LHT, Aarts TL, De Groot JD (1995) The 'wasting disease' and the effect of abiotic factors (light intensity, temperature, salinity) and infection with Labyrinthula zosterae on the phenolic content of Zostera marina shoots. Aquat Bot 52:35-44

Young EL (1937) Notes on the Labyrinthula parasite of eelgrass Zostera marina. Bull Mt Desert Isl Biol Lab, p 33-35

Young EL (1938) Labyrinthula on Pacific coast eelgrass. Can J Res Sect C Bot Sci 16:115-117

Submitted: January 4, 2001; Accepted: May 29, 2001

Proofs received from author(s): January 21, 2002 